\title{
Maintaining Confessional Discourse through Presupposition in Feminist Speech
}

\author{
Lisetyo Ariyanti \\ Universitas Negeri Surabaya \\ Surabaya, Indonesia \\ lisetyoariyanti@unesa.ac.id
}

\author{
Nurul Ulfa Nistiti \\ Universitas Negeri Surabaya \\ Surabaya, Indonesia \\ nurul.nistiti@mhs.unesa.ac.id
}

\begin{abstract}
This research took an online media provided by the TEDxEuston annual events that feature new thinking about Africa and African leadership. This research completed the two research questions that analyzed the types of presupposition used in Chimamanda Ngozi Adichie's speech "We should all be feminist" and determine to what extent the presupposition contribute the confessional discourse of Chimamanda Ngozi Adichie's Speech. The research method was a qualitative research that analyzed the confessional discourse in the text of Chimamanda Ngozi Adichie's speech. The data focused on confessional sentences that were maintained with presupposition expression. The finding shows that Chimamanda Ngozi used the three confessional discourse functions (therapeutic, didactic, and interrogatory) through presupposition types. The presupposition types that contribute those three functions of confessional discourse are existential, lexical, factive, non-facive, structural, and conterfactual. The elaboration between the functions of confessional discourse and the presupposition types has formed results into the main idea of power-sharing agreement. This agreement briefly brought out Chimamanda's main purpose in getting agreement and high trusted from her audiences toward her feminist point of view. The purpose issued the functions into a recognition of personal identity and declaration some suggestive statement. In conclusion, Chimamanda focused her confession on women because the main topic of the speech is about the feminist and to those women who are carelessly concerned in the society. Moreover, presupposition form in the confessional discourse established the connection between the speaker and audience to have the same one point of view.
\end{abstract}

Keywords-presupposition, confessional discourse, feminist discourse, speech

\section{INTRODUCTION}

In the process of communication, people can do their interaction through many ways, including spoken and written way. One of spoken way that people can do is delivering a speech. In this way of communication, speech is used as one way interaction since it is only the speaker that can deliver the nessage; while the audience who cannot give their responds immediately mainly play their role purely as listeners. Speech is delivered by people in formal situation. In addition, speech also aims to persuade, to convey information and also to entertain. Brown and Yule [3] said that people cooperate on simple mechanics of speech. People use those mechanism to reach their goals. In order to reach their goals, people compete each other in their interaction by conducting persuasive expression. There is one way of interaction that people can persuade the audience through his/her speech. During his/her speech, a speaker must maintain their language to make the audience focusing the content of the speech. In this way, a speaker basically has to be persuasive to the audience. In this matter, there is a possibility for linguistic theory to be adopted by the speaker in order to serve certain purposes in a certain context. In this certain context, each linguistics theory has distinctive contextual function to be applied, and in this Chimanda' speech context, a typical confessional language has been used in her speech. This confessional (language) discourse is normally used by women. During her speech, a woman tends to confess her weaknesses to confirm her strength by figuring out what she has passed. Confessional discourse according to Mills [14] is the way of women do their confession to give influence for others to change their point of view in certain situation. This confessional discourse theory is also supported by Mandziukk [13] which means the way of women want to deliver their opinion, view, suggestion which use the implied meaning based on specific history in their life. From both of these theories, confessional discourse is the theory that is used to know how the way women confess something and what is the meaning in their confessional meaning. In this research, analyzing Chimamanda's confession is practically needs a supported analysis of presupposition expression that contain in each confessional discourse function. According to Yule [18] Presupposition can explain information which implies what the speaker says automatically. It provides an explanation that a person's truth is often taken for granted by the addressee. This term is used because a sentence can presuppose and imply another sentence apparently. In this research, it focused on the analysis of presupposition in Chimamanda Ngozi Adichie's speech entitled We All Should Be Feminist which explains the issues of gender and equality of women. Automatically, the data of this research is worth to be deeply analyzed based on feminist discourse. In the feminist discourse, it proposes a feminist theory to analyze the power relation and women as an individual or as member or group, as a victim of male domination. Based on this sub-domination, Mills [14] has displayed how women can gain their power using confessional discourse. This research analyzed the confessional discourse functions in woman speech. The goal of this research is to describe the presupposition types and confessional discourse functions in Chimamanda Ngozi Adichie's speech and also define the relation between the presupposition types and confessional discourse functions. 


\section{METHODS}

Since the purpose of this research are to identify the types of presupposition and the confessional discourse functions, the qualitative method is appropriate to be used in this research. It was also because an analysis of the data is in the form of words, phrases, or sentences that required an explanation. This data have some intended meanings that are able to be recognized clearly. The object of this research was Chimamanda's speech which is titled" We Should All be Feminist”. This research focused in the linguistics features in Chimamanda's speech. Her speech was delivered in TEDxEuston Talk in the December 2012 issue. This research maintained the results of these two research questions, they are:

1. What types of presupposition are found in Chimamanda Ngozi Adichie’s speech "We should all be feminist”?

2. To what extent do presupposition contribute the function of the confessional discourse of Chimamanda Ngozi Adichie's Speech?

The explanation of the second research question is based on the theory of confessional discourse function by Mandziuk [13].

\section{RESULTS AND DISCUSSION}

In analyzing the data, the research certainly needs some main theories and some other supporting theories as references. The following is a review of main theories including the general concept of presupposition in pragmatics and confessional discourse analysis. The first theory which is explained, it revolves on the types of presupposition. Then, the second theory is about confessional discourse function which is based on Mandziuk [13] research.

\section{A. Therapeutic Function and their presupposition types in Chimamanda Ngozi Adichie Speech}

Following Mandziuk's statement of confessional discourse, the first function of confessional discourse is therapeutic function. In this first result, it displays the types of presupposition that brought out the therapeutic function. Based on Yule [18] , presupposition are categorized into six types, they are existential, factive, non-factive, lexical, structural and counterfactual. The result shows that there are three types of presupposition which triggers Chimamanda's confession as therapeutic function. This function of confessional therapeutic is how the confessor holds out the audience about self-realization, self-awareness, and selfdevelopment toward woman.

1) Existential Presupposition in Therapeutic Function

In Chimamanda Ngozi's statement, she said "my own definition" which represents as the existential presupposition. The use of existential presupposition "my own definition" in her statement confirms about her belief about feminist. Indeed, what she tells to her audiences is based on her personal experience in accordance with the facts that occurred at the time. Through existential presupposition, it also belongs to show her self-awareness. She explains her self-awareness through confessing a message that there is a problem about gender now. In which the position between men and women cannot be run in a balanced manner that it should be fixed.

TABLE I. TABLE OF EXISTENTIAL PRESUPPOSITION IN THERAPEUTIC FUNCTION

Existential Presupposition in Therapeutic Function

My own definition of feminist is: a feminist is a man or a woman who says - a feminist is a man or a woman who says "Yes, there's a problem with gender as it is today, and we must fix it. We must do better."

\begin{tabular}{|c|l|c|c|}
\hline $\begin{array}{c}\text { Presupposition } \\
\text { Form }\end{array}$ & \multicolumn{1}{|c|}{$\begin{array}{c}\text { Presuppose } \\
\text { Meaning }\end{array}$} & $\begin{array}{c}\text { Confessional } \\
\text { Discourse }\end{array}$ & The Function \\
\hline Noun-Phrase & $\begin{array}{l}\text { The } \\
\text { Presupposition } \\
\text { expressed } \\
\text { "Chimamanda’s } \\
\text { point of view” }\end{array}$ & Therapeutic & $\begin{array}{l}\text { To show her } \\
\text { self awareness }\end{array}$ \\
\hline
\end{tabular}

2) Therapeutic Function revealed through Factive Presuppotion

In the statement of Chimamanda Ngozi "I decided that I would now call myself "a happy African feminist", she emphasizes the word "decided as the factive presupposition which implies a real fact and truth. Through this presupposition, she can confess her audiences to learn something. It can be proved from her self-development through her presumption about her decision as a feminist. Here, this therapeutic function also emphasizes her personal decision as her self-development to be a role model. So, her audiences can also think the same way. If she becomes a feminist, it does not make a burden to live or create an inconvenience. It can be seen on the word "happy" which means that she wants to emphasize if she wants to become a feminist, she also must feel happy. In other words this assumption also explains that she is a feminist who can still enjoy life and can move forward without having to always rely on men.

TABLE II. THERAPEUTIC FUNCTION REVEALED THROUGH FACTIVE PRESUPPOSITION

\begin{tabular}{|c|c|c|c|}
\hline \multicolumn{3}{|c|}{ Therapeutic Function Revealed Through Factive Presupposition } \\
\hline \multicolumn{2}{|c|}{ I decided that I would now call myself "a happy African feminist." } \\
\hline $\begin{array}{c}\text { Presuppose } \\
\text { Form }\end{array}$ & $\begin{array}{r}\text { Presuppose } \\
\text { Meaning }\end{array}$ & $\begin{array}{c}\text { Confessional } \\
\text { Discourse }\end{array}$ & The Function \\
\hline Sentence & $\begin{array}{c}\text { The } \\
\text { "Wupposition } \\
\text { expressed } \\
\text { Women who is } \\
\text { stll increasing } \\
\text { without any } \\
\text { burden." }\end{array}$ & therapeutic & $\begin{array}{c}\text { To show her self } \\
\text { development }\end{array}$ \\
\hline
\end{tabular}

3) Conterfactual Presuppotion in Therapeutic Function

The above statement (data 3) contains a sentence that has an expressive meaning. That sentence is expressed by 
Chimamanda Ngozi to her audiences that say. "If you are in the breadwinner in your relationship with a man, you have to pretend that you're not". It has truly meaning which is whereas women can do, they have to hide their ability. In this case also reinforced by the word "if" where she conveys a meaning that it is the opposite of the true and contrary to reality. This sentence has a meaning about self-realization in her confession to her audience, if a woman have married, and she still decided to join work to get a salary. The sentence also contains an implied presumption of annoyance that can be seen in the context of "you have to pretend that you're not" which means women have to hide their ability. This occurs because Chimamanda wants to show her self-realization too about the women in reality life. Through her self-realization she can explains that the role of women can change and they can go forward; but, in reality women must stay strong in their position.

TABLE III. TABLE OF CONTERFACTUAL PRESUPPOTION IN THERAPEUTIC FUNCTION

\begin{tabular}{|c|c|c|c|}
\hline \multirow{2}{*}{\multicolumn{4}{|c|}{$\begin{array}{c}\text { Conterfactual Presuppotion in Therapeutic Function } \\
\text { If you are the breadwinner in your relationship with a man, you have } \\
\text { to pretend that you're not, especially in public, otherwise you will } \\
\text { emasculate him. }\end{array}$}} \\
\hline & & & \\
\hline $\begin{array}{l}\text { Presuppose } \\
\text { Form }\end{array}$ & $\begin{array}{l}\text { Presuppose } \\
\text { Meaning }\end{array}$ & $\begin{array}{c}\text { Confessional } \\
\text { Discourse }\end{array}$ & $\begin{array}{l}\text { The } \\
\text { Function }\end{array}$ \\
\hline Sentence & $\begin{array}{l}\text { The } \\
\text { Presupposition } \\
\text { expressed } \\
\text { “Appreantly, the } \\
\text { women can do, } \\
\text { they have to hide } \\
\text { their ability.” }\end{array}$ & Therapeutic & $\begin{array}{l}\text { To show } \\
\text { her self } \\
\text { realization }\end{array}$ \\
\hline
\end{tabular}

B. Type of presupposition in Didactic Function of Chimamanda Ngozi Adichie's Speech

The second subchapter that was explained is the type of presupposition in confessional discourse as therapeutic function. In this research, there are four types of presupposition which related in confessional discourse as didactic function. With some of these presupposition types, Chimamanda can maximize the functionality of the didactic function, so when she configures her statements with this presupposition. She can provide an explanation how she delivers her life experience to the audience. Then, the audience can learn something from. The confessor also gives the option of learning with their real life.

\section{1) Non-Factive Presuppotion in Didactic Function}

TABLE IV. TABLE OF NON-FACTIVE PRESUPPOSITION IN DIDACTIC FUNCTION

\begin{tabular}{|c|c|c|c|}
\hline \multicolumn{4}{|c|}{ Non-Factive Presuppotion in Didactic Function } \\
\hline \multicolumn{3}{|c|}{$\begin{array}{l}\text { We begin to dream about and plan for a different world, fairer } \\
\text { world; a world of happier men and happier women who are truer to } \\
\text { themselves }\end{array}$} \\
\hline $\begin{array}{c}\text { Presuppose } \\
\text { Form }\end{array}$ & $\begin{array}{c}\text { Presuppose Meaning } \\
\text { Sentence }\end{array}$ & $\begin{array}{c}\text { Confessional } \\
\text { Discourse } \\
\text { expressed "Must be } \\
\text { dare to walk together } \\
\text { between man and } \\
\text { women to achieve } \\
\text { their gender } \\
\text { emancipation." }\end{array}$ & $\begin{array}{c}\text { The } \\
\text { Function }\end{array}$ \\
\hline \multicolumn{2}{|c}{ Didactic } & $\begin{array}{c}\text { To find its } \\
\text { lesson }\end{array}$ \\
\hline
\end{tabular}

She emphasized the word "dream" as a form of opposite meaning which indicated that she was using non-factive presupposition, in particular her doubts. It means, they must be dare to walk together between man and women to achieve their gender emancipation. Chimamanda used non-factive presupposition in her confession to support the final outcome of her intention to deliver the learning message to her audiences. The way “dream” emphasizes emotion toward topic of strong women and how women should act give a clear pathway to her. The audiences can catch the message clearly with the help of this presupposition

\section{2) Factive Presuppotion in Didactic Function}

Factive presupposition in the phrase "Gender as it functions today is a grave injustice" expressed by Chimamanda Ngozi explains that gender issues still cannot meet the point of solution. In this sentence she provides information in accordance with the facts that exist, especially about the injustice of women's position. This presupposition type create a trigger of didactic function in Chimamanda Ngozi's statement; so when all the audiences receive the message, the audiences can think that Chimamanda wants to give an indirect warning. In the statement "We should all be angry" she emphasized that women should be angry because in reality the current gender issues are very unfair even women position are still very intimidated. Chimamanda ngozi also wants to invite women especially to dare to dream, dare to stand to make a better change, so they do not become visible weak and small.

TABLE V. TABLE OF FACTIVE PRESUPPOTION IN DIDACTIC FUNCTION

\begin{tabular}{|c|c|c|c|}
\hline \multicolumn{4}{|c|}{ Factive Presupposition in Didactic Function } \\
\hline \multicolumn{2}{|c|}{ Gender as it functionstoday is a grave iniustice. We should all be angry. } \\
\hline Form & Presuppose Meaning & $\begin{array}{c}\text { Confessional } \\
\text { Discourse }\end{array}$ & $\begin{array}{c}\text { The } \\
\text { Function }\end{array}$ \\
\hline Sentence & $\begin{array}{c}\text { The Presupposition } \\
\text { expressed } \\
\text { "an intimidating } \\
\text { condition of gender } \\
\text { emancipation." }\end{array}$ & Didactic & $\begin{array}{c}\text { To give a } \\
\text { warning }\end{array}$ \\
\hline
\end{tabular}

3) Counterfactual Presupposition in Didactic Function

In this function, it can be seen that she confesses her audiences with a lot of many values. She also tries to give a statement through the presupposition "if it is factually true that the full humanity of women is not our culture, then we must make it our culture" to her audiences. It has a meaning that culture is created and related to how the people think. Moreover in this counterfactual presupposition, she explains that these people form the culture, not the culture that makes up society (people). If only it were a fact that women are also part of society that makes culture, then gender issues especially about women's equality can be part of the culture itself. Thus, the emancipation of women can be easily accepted by the public.

TABLE VI. TABLE OF COUNTERFACTUAL PRESUPPOSITION IN DIDACTIC FUNCTION

\begin{tabular}{|c|c|c|c|}
\hline \multicolumn{4}{|c|}{ Counterfactual Presupposition in Didactic Function } \\
\hline $\begin{array}{c}\text { Culture does not make people, people make culture. Soif it's in fact true } \\
\text { that the full humanity of women is not our culture, then we must make it }\end{array}$ \\
\hline $\begin{array}{c}\mid c \text { our culture } \\
\text { Presuppose }\end{array}$ & $\begin{array}{c}\text { Presuppose Meaning } \\
\text { Form }\end{array}$ & $\begin{array}{c}\text { Confessional } \\
\text { Discourse }\end{array}$ & $\begin{array}{c}\text { The } \\
\text { Function }\end{array}$ \\
\hline \multirow{2}{*}{$\begin{array}{c}\text { The Presupposition } \\
\text { the culture that create } \\
\text { how the people thinking, so } \\
\text { the women progress still } \\
\text { can not acceptable." }\end{array}$} & Didactic & $\begin{array}{c}\text { To share } \\
\text { resevoir of } \\
\text { values }\end{array}$ \\
\hline
\end{tabular}


4) Lexical Presupposition in Didactic Function

Ngozi also tries to give a statement through the presupposition "We have evolved; but it seems to me that our ideas of gender have not evolved." to her audiences. The phrases have not evolved has a lexical meaning that it does not change the concept of gender in the society. Moreover in this lexical presupposition, Ngozi imparts a warning that what she has employed so far could not be applied in the society and cannot develop the gender issue improvement. Based on this lexical warning, she expects the audience follow her life experience. She tried to give a lesson by delivering the warning idea of the undeveloped gender issue to her audience.

TABLE VII. TABLE OF LEXICAL PRESUPPOSITION IN DIDACTIC FUNCTION

\begin{tabular}{|c|c|c|c|}
\hline \multicolumn{4}{|c|}{ Lexical Presupposition in Didactic Function } \\
\hline \multicolumn{3}{|c|}{ We have evolved; but it seems to me that our ideas of genderhave not } \\
evolved.
\end{tabular}

\section{Type of presupposition in Interagatory Function of} Chimamanda Ngozi Adichie's Speech

Interagatory function of confessional discourse explains a similar idea of counterfactual presupposition. It shows the results in a contrary understanding of its statements or contradictions with the reality. The same as in the counterfactual presupposition sign, the use of the word "ifclause" makes a contradictory presumption of the utterance delivered.

\section{1) Structural Presupposition in Interagatory Function}

Structural presuposition in Chimamanda Ngozi statement refers to a question form known as a problem which she discusses in her speech about the issue of the gender. This apparent in the phrase "how much happier we would be, how much freer to be our true individual selves ". Based on her statement, she interpretes by emphasizing the question "why". In this case, she rises the questions why only women who are at home and do some homework such as cooking, cleaning houses, etc. And also, whether a woman is born destined to be that way, the social environmental influences have stated that women must be home worked.

Chimamanda's statement, "how much happier we would be, how much freer to be true for gender expectations" which emphasizes the question "how much happier" indicates a structural presupposition to reach the interagatory function. In this case, her structural presupposition has full control to make the audience have same point of view by giving the question to her audience. In this way, the audience would think about and discuss the problem of gender issues. Within the question word being used, the audience would likey become motivated by the message she delivered.
TABLE VIII. TABLE OF STRUCTURAL PRESUPPOSITION IN INTERAGATORY FUNCTION

\begin{tabular}{|c|c|c|c|}
\hline \multicolumn{4}{|c|}{ Structural Presuppotion in Interagatory Function. } \\
\hline \multicolumn{4}{|c|}{$\begin{array}{c}\text { Now imagine how much happier we would be, how much freer to be } \\
\text { our true individual selves, if we didn't have the weight of gender } \\
\text { expectations }\end{array}$} \\
\hline $\begin{array}{l}\text { Presuppose } \\
\text { Form }\end{array}$ & Presuppose Meaning & $\begin{array}{c}\text { Confessional } \\
\text { Discourse }\end{array}$ & $\begin{array}{c}\text { The } \\
\text { Function }\end{array}$ \\
\hline Sentence & $\begin{array}{l}\text { The Presupposition } \\
\text { expressed } \\
\text { "the condition is not } \\
\text { being happy, if the } \\
\text { women position still } \\
\text { be descriminated. }\end{array}$ & Intregatory & $\begin{array}{l}\text { To rise an } \\
\text { question as } \\
\text { the } \\
\text { motivation }\end{array}$ \\
\hline 2) & $\begin{array}{l}\text { tion } \\
\text { tionfactual }\end{array}$ & position & Interas \\
\hline
\end{tabular}

In the form of her statement above (Data 9), Chimamanda Ngozi does not only use a question sentence, but she also intend to express counterfactual presupposition. The meaning of this counterfactual presupposition conveyed an implied information of satire. Through that sentence, it provides a presupposition meaning that if women can live as well as men. The prefixed sentence can be seen when Chimamanda states the phrase "what if we question the premise itself, why should a woman's success be a threat to a man?". This presupposition has a meaning that successful women are considered to threaten the position of men. The sentence asked by Chimamanda for her audiences has a purpose for them to think, what if successful women can threaten the position men. When in fact women still cannot explore their abilities especially if they have to work, with this assertion Chimamanda explains how women can be successful.

TABLE IX. TABLE OF COUNTERFACTUAL PRESUPPOSITION IN INTERAGATORY FUNCTION

\begin{tabular}{|c|c|c|c|}
\hline \multicolumn{3}{|c|}{ Counterfactual Presupposition in Intregatory Function } \\
\hline \multicolumn{2}{|c|}{ what if we question the premise itself, why should a woman's success } \\
be threat to a man? \\
$\begin{array}{c}\text { Presuppose } \\
\text { Form }\end{array}$ & \multicolumn{1}{|c|}{$\begin{array}{c}\text { Presuppose Meaning } \\
\text { Sentense }\end{array}$} & $\begin{array}{l}\text { Confessional } \\
\text { Discourse } \\
\text { expressed } \\
\text { "Succesfull women are } \\
\text { considered to threaten } \\
\text { the position of men." }\end{array}$ & $\begin{array}{c}\text { The } \\
\text { Function }\end{array}$ \\
\hline
\end{tabular}

Based on the analysis of the second research question, the result have conducted that Chimamanda's confessional discourse has brought two conditions related to Manziukk's confessional discourse function, they are:

\section{1) To recognize personal identity}

The first main point in this research is to recognize personal identity. It confirms that Chimamanda's statements that she describes to her audiences is based on her personal 
experience. Rosenthal (1994) shows that personal identity is largely concerned to the basic values that dictate the choices someone makes which reflect who someone is. In this case, Chimamanda confirms her belief in the statement that she is a feminist. She has a point of view on how to define public's opinion should be. Therefore, when she raises her perspective on what the definition of feminist to her audiences, the message can be clearly communicated based on her point of view. Then, through Chimamanda presupposition expression in her speech, her audience would like to use it as a role model to her audience. Yingfang states [16] that one of presupposition features is being the "shared background information", concur with the psychological condition of the interlocutors. In this way, the psychological condition of the interlocutors is influenced by the background belief of the speaker. When the audience have understood the personal identity of Chimamanda, she can take advantage of the psychology of her audience to serve her purpose.

\section{2) To Declare Some Suggestive Statements}

The second condition has brought the issue of declarating some suggestive statements. According to Yeates (2016: .3536), suggestion statement is the psychological process by which one person guides the thoughts, feelings, or behavior of another person. Chimamanda uses presuppositions in this confessional discourse functions to emphasize the real situation of people's views on gender equality, so that the audience can realize how they should behave. She emphasized that they have to be sensitive because in reality the current gender issues are very unfair, even for the position of women who are still very intimidated. Chimamanda Ngozi also wants to invite women especially to dare to dream, dare to stand to make a better change, so they do not become visible weak and small. She tried to explain empirically her strong, feeling, and emotion to give influence her audiences about this problem, then the audiences can have the same feeling. This confession also make her audiences can realize to think the same thing with her about woman position.

\section{CONCLUSION}

This research has concluded that both of the types of presupposition and the confessional discourse functions can be involved each other to analyze the speech of Chimamanda Ngozi Adichie's entitled "We All Should be Feminist". The result brings the main idea of power-sharing agreement which means the main purpose of Chimamanda's presupposition types through confessional discourse functions in her speech is to get agreement and high trusted from her audiences about her feminist point of view. By recognizing of personal identity and the suggestive statements, Chimamanda focused on expressing her feeling about women position in society. Mostly, her confession is about women because the main topic of the speech is about the feminist and women position. She brought some kind of hurtful comment toward women which she should speak up since it is horrible situation. That is a way she confessed everything in her speech centered about women in her expectation. Moreover, using presupposition expressions in the confessional discourse in Chimamanda's speech is very significant, because they are the bridge to make connection between the speaker and audience to have one point of view.

\section{REFERENCES}

[1] Anjani, F., Confessional Discourse of Michelle Obama Speech. Unesa, 2016.

[2] Bonyadi, A., "Linguistics Nature of Presupposition in American and Persian Newspaper Editorials”, International Journal of Linguistics, 2011.

[3] Brown, Gillian \& GeorgeYule, Discourse Analysis. University of Cambridge: Press Syndicate, 1988

[4] Carston, R., “Negation, 'presupposition' and the semantics/pragmatics distinction”, International Journal of Linguistics, 2000

[5] Cruise, A., A Glossary of Semantics and Pragmatics. Finland: Edinburgh University Press, 2006.

[6] Cutting, J., Pragmatic and Discourse. New Fetter Lane: London: Routledge, 2002.

[7] Geoffrey, F. A., Key Concept in Language and Linguistics. Hamshire: Palgrave Macmillan, 2000.

[8] Griffihs, P., An Introduction to English Semantics and Pragmatics. Edinburgh: Edinburgh University Press, 2006.

[9] Grundy, P., Doing Pragmatics. Madison avenue: New York: Oxford University Press, 2000.

[10] Hans-Jorg, S., "Presupposition can be bluff”, International Journal of Linguistics, 1529-1552, 2001.

[11] Indah, R., "The use of presupposition in business model canvas of start friday's”, Language Horizon, 2016.

[12] Litosseliti, L., Research Methods in Linguistics. London and New York: Continuum, 2010

[13] Mandziuk, R., “Confessional discourse and modern desires: power and please in true story of communication at the southwest texas state university, san”, Journal of Pragmatics, 2001.

[14] Mills, Sara, Discourse. New York: Routledge, 1997.

[15] Rachmawati, I. C., "Revealing the function of reference in presupposition of english”, Language Horizon, 2016.

[16] Rivers, E. L., Two Functions of Social Discourse: From Lope de Vegato Miguel de Cervantes. Oral Tradition, 1987.

[17] Yingfang, Wang, "Analysis of presupposition and its function in advertisements”, Canadian Social Science: Vol.3 No.4, August 2007

[18] Yule, G., The Research of Language. The United States of America by Cambridge University Press, New York, 1996.

[19] Yule, G., Pragmatics. Oxford University Press. (S.D.), 2006. 